\title{
A Holistic Educational Paradigm Managing coastal resources in the Philippines
}

\section{Paul Watts}

DALUHAY, www.ecosystemics.info

\section{Eduardo Macose}

Aurora State College of Technology
Eusebio Angara

Aurora State College of Technology

Marivic Pajaro

Aurora Marine Research and Development Institute
Gateways: International Journal of Community Research and Engagement Vol 3 (2010): 120-138 CUTSePress and the authors

ISSN 1836-3393
The world is facing a depletion of marine resources that threatens entire cultures and endangers the very life of the planet. Reports indicate that over 80 per cent of world fish stocks are heavily exploited or depleted, yet close to 200 million people continue to depend on the fishery for livelihood (FAO 2008). The vast geographical range of many marine fish populations calls for public participation, communication and coordination on a large scale, all of which may be critical to maintaining the health of coastal resources, as well as the delivery of ecosystem services.

The need for public participation is enhanced in those countries where both government services and marine management infrastructure are limited. In the Philippines, public participation has been identified as a priority strategy to promote sustainable development of coastal resources (Republic Act 8435, Akester et al. 2007). Given the lack of empowered stakeholders and a functional government body that can appropriately address the challenges of coastal resource management through public participation, catalyst institutions need to step in. This role is being undertaken by the Aurora State College of Technology (ASCOT), located in Aurora Province on the northeast coast of Luzon Island, Philippines. ASCOT has adopted a holistic approach that offers a model for responsive education with a focus on participation and representative leadership. Although universities and colleges have generally acknowledged their connection to their surrounding environment and link theory with practical application in communities (Lowes \& Reisch 1998), the ASCOT program is specifically aimed at cultural transformation as an approach to sustainability in the coastal environment. The focus is on communication and coordination for large-scale coastal resource management and sustainability.

Some research in developing countries has specifically identified the importance of involving authorities within public partnerships (Choguill 1996). This is in contrast to early international work on public participation, which identified citizen control as the primary goal and highest level of activity, while 
partnerships with authorities were ranked third in significance (Arnstein 1969). However, these initial categories did not consider leadership needs in areas such as technical ecosystem management, or educational development and learning (Reed 2008).

In the current work, we outline ASCOT's ongoing programs as an example of a 'catalyst institution' in action, with a focus on responsive education through strategic partnerships and public participation. As an example of public participation, we report on a case study of research conducted with the Aurora Province fisherfolk and Pamana, a national alliance of fisherfolk Marine Protected Area (MPA) managers.

\section{THE COASTAL RESOURCE MANAGEMENT CHALLENGE}

The coastal resource management (CRM) challenges that ASCOT is responding to are a reflection of the country's profile of coastal resources and livelihoods. The Philippines has the fifth largest coastline in the world - over $6000 \mathrm{~km}$ longer than that of the entire continent of Africa. The review of Asian coastal fisheries by Silvestre and Pauly (2004) provided data that compared the nine developing countries with populations greater than 20 million (Bangladesh, India, Indonesia, Malaysia, Mayanmar, Pakistan, Philippines, Thailand and Vietnam). Additional calculations reports indicate that the Philippines is identified as a hotspot and a global priority for conservation because of its mega diverse marine fauna, notably reef fishes, corals, molluscs and other invertebrates (Carpenter \& Springer 2005; Roberts et al. 2002). However, it also ranks first in marine ecosystem use, dependence and influence. The per capita Philippine consumption of fish is the highest at $36 \mathrm{~kg} /$ year, in part due to a land base that is limited to just $300000 \mathrm{~km}^{2}$. The influence of the country on global marine systems is demonstrated through the relationship between the size of the Exclusive Economic Zone (EEZ) and the land area of the country. The Philippines again ranks first within the nine large Asian countries at $5.95 \mathrm{~km}^{2}$ of EEZ per $\mathrm{km}^{2}$ of land, over twice that of Vietnam or Indonesia.

The primary CRM challenges in the Philippines include declining fish catches, degradation of coastal habitat, conflict amongst resource users, poverty amongst artisan fisherfolk and increasing food deficiencies (Luna et al. 2004a,b). These conditions are significant issues affecting provision of the country's protein needs as well as export income and livelihoods (Barut, Santos \& Garces 2004). For example, the poverty level in fisherfolk families has been reported to be about 62 per cent, approaching twice the national average (Israel 2004). Although Santos (2004), analysing Department of Environment and Natural Resources (DENR) data, found a five-fold increase in fish production (total weight of fish catch) in the past 35 years, the paper also reported catch per unit effort (CPUE) had dropped by 90 per cent. The situation is complicated by the fact that the ocean and fishing are often seen 
as a last resort for livelihood and income generation. An increase in the number of fisherfolk or in time spent fishing can create competition that effectively reduces the quality of the livelihood of fisherfolk, the wellbeing of their families and the health of the ecosystem.

In the Philippines, there is a significant relationship between population levels and the state of fisheries resources (Alino et al. 2004b). Large population increases in the Philippines tend to push people into fishing due to the general lack of alternative livelihoods (Townsend 2004). At the same time, there is a tendency for reductions in fish harvest to result in forest degradation, as residents are forced inland to support their families. In the Philippines over 90 per cent of the forests have been removed, leaving Aurora the most highly forested province, with over 70 per cent cover still remaining (Ong et al. 2002). Recent reported declines in the Aurora Province marine fishing sector (Mamauag 2004) have been dramatic, and as marine biodiversity and biomass are depleted, further pressure may be put upon terrestrial biodiversity. The Philippine Biodiversity Conservation Priorities Program (Ong et al. 2002) identified Aurora Province as a high biodiversity conservation priority for forest systems as well as for specific marine categories.

Globally, managed Marine Protected Areas (MPAs) are considered one of the most effective tools for the rehabilitation of coastal resources. There are an estimated 4600 MPAs throughout the world (Woods 2006). However, there is an urgent need to advance the increasingly successful, but generally local and small-scale coastal MPA strategies to larger ecosystem units such as bioregions (UNESCO 2009). For example, in terms of scale, MPAs represent just a few hectares each and number over 600 in the Philippines (Alcala \& Russ 2006), while the entire coastal waters of the country are divided into just six marine bioregions (Ong et al. 2002). A bioregional approach is perhaps the best next step for Philippine marine planning, which so far has invested significant efforts in establishing MPAs as an application of the ecosystem approach. The expansion of the ecosystem approach to Philippine bioregions has perhaps been limited in part by the historic development of terrestrial administrative regions, thus complicating marine ecological considerations (Dizon-Corrales 2004). Many non-government organisations and researchers, however, are now focused on the need for further integration of the ecosystem approach and coastal resource management efforts (Adan 2004; Barut, Santos \& Garces 2004; Hermes 2004a; Luna et al. 2004a,b; Pido 2004), though biodiversity-based marine bioregions have only recently been given institutional attention in the Philippines (Ong et al. 2002).

Aurora Province, where ASCOT is situated, lies in the North Philippine Sea (NPS) bioregion (Ong et al. 2002), stretching between the east coast provinces of Sorsogon in the south and Batanes in the north. In general, the Philippine Eastern Seaboard 
has been found to have reduced primary productivity and coral reefs are significantly poorer in quality than those of other fishing areas of the Philippines (Gomez et al. 2004). However, the Philippine Eastern Seaboard is generally seen as an area where fish capture could be increased, due to the fact that it 'produces' a limited portion of the Philippine fish harvest (Gomez at al. 2004). These perspectives appear to be in disagreement with participatory fisheries data from Aurora Province. Between 1989 and 2002, Aurora's 10000 residents directly associated with fishing experienced a 57.5 per cent decrease in marine harvest and a 63 per cent decline in CPUE (Mamauag 2004).

The status of deepwater and highly migratory fish stocks, such as those of tuna, illustrates the need for a larger scale approach to managing ecosystem services. Currently the Municipal Local Government Units (MLGUs) have jurisdictional responsibility for coastal resource management and fisheries. The Province of Aurora is divided into seven independent municipal fisheries; however, application of an MPA and coastal planning tool (Licuanan et al. 2006) indicates that collaboration needs to occur between jurisdictions and in some cases beyond provincial water boundaries. The MLGU jurisdiction extends out only $15 \mathrm{~km}$ from the shoreline, while commercial fisheries operate on a separate system starting at $15 \mathrm{~km}$ offshore and extending out to the border of the EEZ. This produces conflict between municipal and commercial harvest (Zaragoza, Pagdilao \& Moreno 2004a, b), but, while there is a high level of tuna harvest, there is also a lack of information available on deepwater fisheries and organisms compared to their shallow water counterparts (Flores 2004). Along with the establishment of bioregions, a process to initiate interprovincial public participation and links between commercial and municipal fisheries appears necessary, as well as a step forward in terms of marine spatial planning that includes the use of massenergy models (Christensen \& Pauly 1995, 1996) as suggested elsewhere (UNESCO 2009).

\section{RESPONSIVE EDUCATION PROGRAMMING}

The complex, large-scale and urgent nature of the problems in the Philippines necessitates the active involvement of institutions that can respond in a multi-layered, holistic way. There are several reasons why educational institutions are especially well placed to take on this role. Education represents a stable funding framework and an environment where the exchange of ideas, building of consensus and initiation of local action programs can occur. Further, the balance between the three tertiary education functions of extensions, teaching and research provide a holistic framework to facilitate cultural and local transformation. Also, the core budget for the state education system is not hampered by specific business or financial goals but rather has a 'service first' mandate, based upon government funds. Finally, academic programs are not directly controlled by government, which can allow institutions 
to be a catalyst towards integrating public participation with jurisdictional activities. In the Philippines, as a result of related economic and infrastructure limitations, fisherfolk are in general expected to actively engage in determining the sustainability of their own livelihood and ecosystem services. The establishment of coordinated sequential educational activities (elementary school to college and adult education) on fisheries resource management may therefore be of particular significance.

ASCOT was established in 1993 to provide local access to tertiary education and to help address the development challenges of Aurora Province. It envisions itself as a centre of excellence in various programs of teachings and a lead provincial academic institution with developed expertise in key areas of research. The ASCOT vision also includes leadership in community/extension services, sustainable development initiatives in the province and the establishment of strong linkages beyond Aurora. ASCOT is evolving a highly functional networking mechanism with local and international universities and institutions through communication and coordination. ASCOT is committed to developing human resource potential through quality training that is responsive to the needs of the people in the province in particular and the nation in general, and to serving as a catalyst and facilitator of the provincial development efforts in food security, poverty reduction, health care and preservation of the incredible biodiversity of the province.

Recently, ASCOT, in partnership with Aurora Province and the Maximo T. Kalaw Institute for Sustainable Development (Roxas 1984, 2006), initiated an ecosystem-based, communitycentred participatory approach to development involving an integration of agricultural, forest and marine ecosystems. The ASCOT marine portion of the program (titled Aurora Province and the global village coastline: Communication and coordination) is intended as a holistic response to the marine challenges through a transdisciplinary approach. The program has three distinct but related areas of activity: strategic partnerships, public participation, and responsive education. This ASCOT approach was developed through analysis of the current situation in Aurora Province and various national needs perspectives related to the marine environment (Alino et al. 2004b; Eisma 2004; Hermes 2004b; Silvestre \& Pauly 2004). It is a response to the need for a strengthening of institutions (Silvestre \& Pauly 2004), based upon the idea of using existing education infrastructure to enhance, reform and develop goal-orientated public participation. Emphasis is on communication, coordination and cooperation at all levels: from local to international, from mountains to marine, as discussed elsewhere (McGlone et al. 2004). In effect, ASCOT is refocusing disciplines and other academic activities to respond to a specific national challenge. The collaborative and landmark reference library organised by the Department of Agriculture- 
Bureau of Fisheries and Aquatic Resources (DA-BFAR 2004) provided ASCOT with a focus and starting point for its current activities.

The ongoing ASCOT programs also take into account the fact that the culture is relationship-based (Pakikipagkapwa), as demonstrated by 'money sent home' being the largest source of foreign currency in the country. One challenge is to extend and develop this characteristic that exists at the personal level to encompass communities that share ecosystems. Reflecting this, ASCOT has taken an ethnoecology approach to its engagement activities whereby humans are considered an integral part of the ecosystem (see www.ecosystemics.info). This is in contrast to the traditional production- or harvest-based approach, which tends to see humans as external to the ecosystem. In essence, this application of ethnoecology involves a validation of cultural perspectives on the environment as a prerequisite to any suggestions of change.

There is also good political cooperation between all levels of government within the Province of Aurora, which is of particular significance in developing a multi-jurisdictional approach. As well, a provincial focus for coastal resource management would make it possible to apply provincial land use plans to the concept of marine sustainability, as suggested elsewhere (Pinat \& Green 2004). The ASCOT program could also be a significant contribution towards ensuring public participation in the establishment of an inter-provincial approach to offshore marine sanctuaries, which has been identified as a Philippine priority (Hermes 2004b), as well as helping to meet the advocacy needs (Pestaño-Smith 2004) associated with sustainable ecosystem services. Consequently, ASCOT's three-pronged response to the conditions in the Republic of the Philippines may also be of use in defining Asian-based input on global marine sustainability. This approach to partnerships, participation and education could perhaps also be applied to other cultures and jurisdictions beyond the Philippines.

\section{STRATEGIC PARTNERSHIPS}

The partnership, advocacy and research activities of ASCOT are directed at creating a common agenda encompassing jurisdictions, academe and fisherfolk. In the past decade, ASCOT initiated a coastal resource management research and development project with assistance from Volunteer Services Overseas Philippines and funding from the Spanish government. In 2005 an initial Memorandum of Understanding (MOU) was signed to strategically link this ASCOT initiative with the Aurora Province Inter-Local Government Unit Coastal Resource Management Committee (ILCRMC), which was itself initiated by the Philippine ECOGOVERNANCE Program and the University of Philippine Marine Science Institute (Orencio 2008). The goal was to form a 
collaborative province-wide programmatic approach to coastal resource management and marine fisheries.

The collaborative ASCOT-ILCRMC program is intended to facilitate mechanisms for effective management of 'communal property rights' (Berkes \& Folke 1998) and is in essence an example of 'parametric fisheries management' (Acheson et al. 1998), focusing on fisherfolk participation and how fishing occurs at a local and then bioregional level, rather than how much fish is taken. A broader MOU establishing joint action steps for interprovincial collaboration along the shores of the North Philippine Sea is one of the next steps in this participatory process, a step that has been endorsed by several national agencies. Local government alliances are a key development in Philippine coastal resource and fisheries management (Adan 2004). However, while jurisdictions are limited by political boundaries, ASCOT's role is to facilitate a collaborative and broader ecological-based participatory approach, while respecting jurisdictional mandates.

Although ASCOT does not have the resources to investigate all fisheries' challenges, existing expertise and current proposed research programs will form a strong base for strategic partnerships. For example, ASCOT has a strong faculty program on mangroves, an area that is of significance in fisheries management (Alava \& Cantos 2004; Barut, Santos \& Garces 2004; Israel 2004; Jatulan 2004; Luna et al 2004a; White \& DeLeon 2004). Mangrove conservation and development has been found to be a subject that stimulates dialogue and other forms of participation by Aurora fisherfolk. Mangroves could thus form an area of specialty in future ASCOT research programs, based in part on its already existing faculty strengths.

In addition to the local focus, the ASCOT CRM program is also intended as a responsive contribution to meeting the challenges identified within Philippine marine fisheries in general. Identifying and acting upon local research needs is considered to be part of an iterative program that will contribute to the often identified national marine information shortages (Flores 2004; Silvestre \& Pauly 2004; Zaragoza, Pagdilao \& Moreno 2004a) and be a contribution to the convergence of adaptive ecosystem management strategies (Alino et al. 2004a). One ASCOT goal for development is to ascend the levels of public participation with the initial aim of local empowerment leading to larger scale input, consensus, advocacy and sustainability. The objective is to implement a systematic coordination of province-wide jurisdictional responsibilities, interests and resources, as well as to mandate partnership development through inter-provincial, national and international linkages.

The ASCOT approach to building organisational and interjurisdictional relationships is conceptually based on the cultural characteristic of family and community level ties, the sense of helping others. As part of this strategy, relationships are developed and supported through a systematic approach to scheduled 
meetings, synthesis of information, participatory approaches to consensus building and action-orientated research for sustainable development, with emphasis on focal group discussions (FGDs). The strategic involvement of jurisdictional representatives and the national fisherfolk alliance, Pamana, in local fisherfolk collaboration is an applied approach to expert/authority partnerships with the public (Choguill 1996) that contributes to both development and participation goals.

\section{PUBLIC PARTICIPATION}

In the past 20 years the fish catch per unit effort in Aurora Province has dropped by about 60 per cent (Mamauag 2004). It is unreasonable to suggest or legislate that fisherfolk must stop feeding their children through the only livelihood option open to them. There is a clear need to work with People's Organizations and involve them in the process of defining sustainable livelihoods and the changes in fisheries management that are also needed to sustain ecosystem services. Globally, similar integrated approaches to linking social and ecological systems are being used (Berkes \& Folke 1998). In essence, the ASCOT approach to public participation involves an iterative strategy of focal group discussions (FGDs) with fisherfolk barangays (the smallest local government unit (LGU) within municipalities) and People's Organizations, balanced by internal and external assessments, review and resultant action. It establishes a process for participation that shares knowledge (traditional and scientific) and perspectives on marine resources throughout the marine bioregion and even globally. The ASCOT use of the FGD approach evolved through its collaboration with Volunteer Services Overseas over the past decade. Initially, it was used on an ad hoc basis but has recently been institutionalised through the office of the ASCOT Planning Officer. In addition, the recently established Aurora Marine Research and Development Institute (AMRDI), which is administered by ASCOT in collaboration with other agencies, uses FGDs as a cornerstone for all stakeholder engagement. Experts and jurisdictional representatives sometimes have a role in defining FGD topics and facilitating dialogue amongst fisherfolk, while also providing analysis and in many cases strategic documentation. FGDs can be used to promote public participation and collect information on specific topics for both research and specific administrative goals. Below is an example of one FGD initiative, which is focused on the development and engagement of fisherfolk communities in terms of ecohealth.

\section{Case Study: The Aurora Fisherfolk Ecohealth Initiative}

There is a growing global awareness that human health is directly linked to the health of the environment. The term 'ecohealth' was created to represent this conceptual merger of people and the environment in what can be more broadly considered as an ethnoecology approach, where people are considered as a part of the ecosystem. Pamana, as a national alliance of fisherfolk Marine 
Protected Area (MPA) managers, represents a grassroots approach to creating and developing Ecohealth Practitioners (Añabieza et al. 2010).

In 2009, Aurora Province held a symposium on ecohealth, which was co-sponsored by Pamana, the department of health, jurisdictional CRM representatives, and ASCOT. In part, Pamana provided fisherfolk experts who assisted in stimulating the participatory process, based upon their experience. FGDs were utilised as an approach to planning, development and the building of consensus. Representatives from fisherfolk communities from across the province were split into four groups of peers, by location (northern or southern) and again according to occupation (fisherfolk or health workers). Specifically, ASCOT adopted the social artistry approach called Salunoron (which includes music and other forms of applied artistry) during the FGDs, as developed by the Bagong Lumad Artists' Foundation Inc. (Vicente 2009) to facilitate non-grammatical inputs that are culturally relevant to the Philippines.

Topics covered during the symposium were grouped into three categories: food systems and marine resources; environment and health; and future trends associated with population and climate change. The FGDs yielded information on the perceptions of the participants in terms of the importance of marine resources, in particular as sources of protein and as traditional medicine. All participants indicated a strong interest in protecting the health of the environment, especially as it relates to human health and food security. A few Marine Protected Areas have already been established by Aurora Province fisherfolk, and there is local interest in expanding upon this emerging network, in part through Pamana Ka sa Pilipinas. Clearly, many of the goals will involve interbarangay, inter-municipal and even inter-provincial cooperation to respond to some of the specific challenges. Watershed approaches to environment and human health could perhaps best be initiated within specific barangays and/or groups of barangays.

In 2010, following the conference, the Provincial Health Department took a leadership role, built on the unanimous agreement of the symposium participants for further collaborative volunteer activities. The ecohealth participatory approach is being used to determine program and implementation gaps within certain individual barangays. Specific barangays have been identified to help focus on the health of small-scale fisherfolk and their families. ASCOT, in partnership with the University of the Philippines Marine Science Institute, is currently establishing the Aurora Marine Research and Development Institute, and adopting the ecohealth approach to fisherfolk related research as a main focus of the CRM program.

In summary, the initial results of the workshop (Table 1, overleaf) are being used to determine local, regional and provincial action plans. This ongoing participatory strategy could provide a catalytic effect for positive change across the bioregion 
Table 1: Summary of FGD results: Southern Aurora Fisherfolk (SAF), Southern Aurora Health Workers (SAHW), Northern Aurora Fisherfolk (NAF) and Northern Aurora Health Workers (NAHW). and in other Philippine areas as a form of action research, as outlined elsewhere (Reason \& Bradbury 2008), making it potentially of national and even global significance.

\begin{tabular}{|c|c|c|c|c|}
\hline Discussion Points & SAF & SAHW & NAF & NAHW \\
\hline \multicolumn{5}{|l|}{ Nutrition } \\
\hline Rice & $50 \%$ & $25 \%$ & $10 \%$ & $50 \%$ \\
\hline Fish diet & $25 \%$ & $33 \%$ & $70 \%$ & $25 \%$ \\
\hline Catch set aside for food & $20 \%$ & $20 \%$ & $1 \mathrm{~kg}$ & $20 \%$ \\
\hline Catch & & $10 \mathrm{~kg}$ & & $3-100 \mathrm{~kg}$ \\
\hline \multicolumn{5}{|l|}{ Current challenges } \\
\hline $\begin{array}{l}\text { Improper sewage/waste/garbage disposal; } \\
\text { unsanitary conditions }\end{array}$ & $\checkmark$ & $\checkmark$ & $\checkmark$ & $\checkmark$ \\
\hline Contaminated/polluted waters & $\sqrt{ }$ & $\checkmark$ & $\checkmark$ & \\
\hline Kaingin (slash and burn) farming & $\checkmark$ & $\checkmark$ & & \\
\hline Flooding & $\checkmark$ & & & $\checkmark$ \\
\hline Stagnant waters that carry disease & $\checkmark$ & & & $\checkmark$ \\
\hline $\begin{array}{l}\text { Shortage of good fish supply/low fish catch; } \\
\text { best fish is exported }\end{array}$ & & & $\checkmark$ & $\checkmark$ \\
\hline Illegal logging & $\checkmark$ & & & \\
\hline Unemployment & & & & $\checkmark$ \\
\hline Malnutrition & & & & $\checkmark$ \\
\hline \multicolumn{5}{|l|}{ Future challenges } \\
\hline Scarcity of harvest; depletion of fish stocks & $\checkmark$ & $\checkmark$ & & $\checkmark$ \\
\hline Overpopulation; immigration & $\sqrt{ }$ & $\checkmark$ & $\checkmark$ & $\checkmark$ \\
\hline $\begin{array}{l}\text { Increased disease (diarrhoea, malaria, dengue, } \\
\text { parasitism) }\end{array}$ & $\checkmark$ & & & $\checkmark$ \\
\hline Effects of climate change & $\checkmark$ & & & $\checkmark$ \\
\hline Kaingin (slash and burn) farming & $\checkmark$ & & & \\
\hline Pollution & & $\checkmark$ & & \\
\hline Lack of alternative livelihoods & & $\checkmark$ & & \\
\hline Forest depletion & & $\checkmark$ & & \\
\hline More floods & & & $\checkmark$ & \\
\hline Increase in fish prices & & & $\checkmark$ & \\
\hline Increased malnutrition in children & & & & $\checkmark$ \\
\hline \multicolumn{5}{|l|}{ Solutions } \\
\hline Solid waste management/segregation/landfill site & $\checkmark$ & $\checkmark$ & $\checkmark$ & $\checkmark$ \\
\hline $\begin{array}{l}\text { Alternative livelihood; livelihood development } \\
\text { programs }\end{array}$ & $\checkmark$ & $\checkmark$ & $\checkmark$ & $\checkmark$ \\
\hline Protection and management of local marine resources & $\checkmark$ & $\checkmark$ & $\checkmark$ & $\checkmark$ \\
\hline Proper sanitation/sewage management & $\checkmark$ & & $\checkmark$ & $\checkmark$ \\
\hline Self-discipline/attitude change in individuals & $\checkmark$ & & $\checkmark$ & $\checkmark$ \\
\hline Education campaigns/programs; sharing knowledge & $\checkmark$ & $\checkmark$ & & $\checkmark$ \\
\hline Family planning; formulate reproductive health law & $\checkmark$ & $\checkmark$ & & $\checkmark$ \\
\hline Regulate fish mesh size & $\checkmark$ & $\checkmark$ & & \\
\hline Government assistance & $\checkmark$ & & $\checkmark$ & \\
\hline Fisherfolk coordination/cooperation programs & $\checkmark$ & & & $\checkmark$ \\
\hline $\begin{array}{l}\text { Strict penalties for illegal environmental infractions; } \\
\text { implementation of laws }\end{array}$ & & $\checkmark$ & & \\
\hline Tourism development & & & $\checkmark$ & \\
\hline Proper implementation and advocacy of programs & & & & $\checkmark$ \\
\hline
\end{tabular}




\section{FUTURE EDUCATIONAL ACTIVITIES}

\section{Teaching}

ASCOT has proposed to establish a marine science program with two areas of specialisation: coastal resource management and marine technology. The ASCOT teaching program will focus on using education holistically, as a venue for participation, reform and development. In the past, many excellent interventions throughout the Philippines have not continued after initial project funding was exhausted. It is hoped that by building upon the sustainability of the education infrastructure to institutionalise participation this tendency will be avoided. Figure 1 shows the proposed framework, which will have input to teacher training as well as direct influence on secondary and elementary schooling.

Figure 1: Integrated education framework of Aurora State of Technology (ASCOT) for coastal resource management and biodiversity conservation program in Aurora province, Philippines.

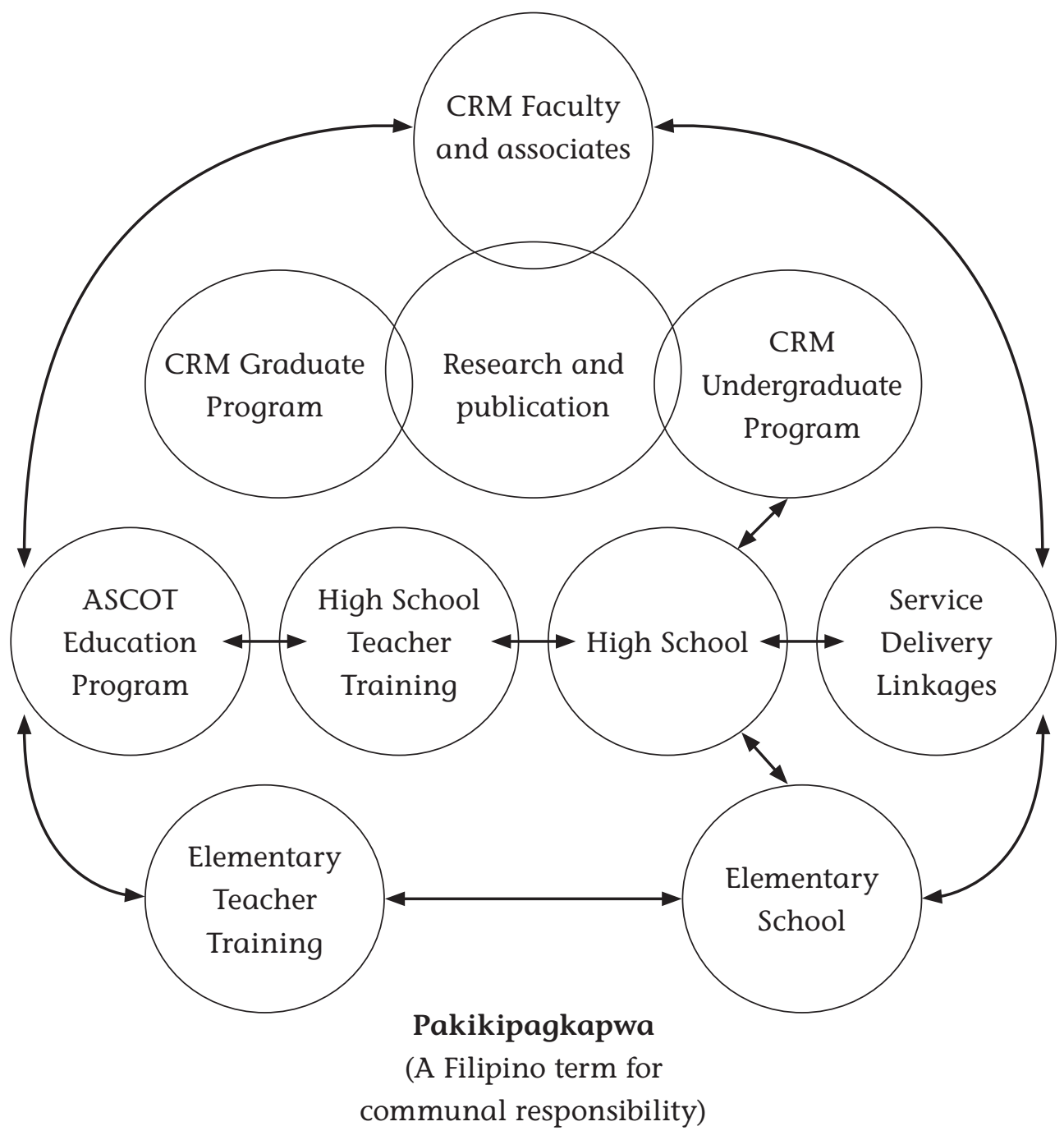

The full operation of the undergraduate marine program that is currently waiting for budgetary approval is expected to start in 2012 or 2013. This undergraduate offering will include four or five years of study in the existing Faculty of Forestry and Environmental Science. A primary focus is to provide graduates with tools for participatory facilitation. A combination of training in science, governance and social development that is directly linked to both local job opportunities and provincial fish landing sites (Carreon 2004) will provide opportunities to contribute to 
collaborative projects focused on municipal (Trudeau 2004) and commercial fisheries licensing issues (Alesna, Dizon-Corrales \& Cabangbang 2004) as well as enforcement (Guidote 2004) and related misunderstandings (Luna et al. 2004b).

The balance of courses between governance, marine science and participatory approaches to development will be initiated in year two. Table 2, below, presents a draft outline of course titles, followed by a brief description of the courses focused on participatory development.

Aurora State College of Technology

Marine \& Coastal Resource Management Core Courses, Year 2

\begin{tabular}{lcl}
\hline Marine Science & Governance & Participatory Development \\
\hline 1. Principles of Ecology & 1. Municipal Governance & 1. Community Development I \\
2. Oceanography & and CRM Mandates & 2. Community Relations \\
3. Marine Ecology & 2. Provincial Governance & 3. People's Organizations \\
4. Ichthyology & and CRM Mandates & 4. Forestry and Agricultural \\
5. Invertebrate Zoology & 3. National Governance and & Land Use \\
& CRM Mandates & \\
\hline
\end{tabular}

Community Development I. The sustainable development courses in the program will be divided into two Community Development offerings, with the first course focusing on background requirements and relationships for the initiation of a sustainable development framework. Sustainable development will be examined as a specific application of the ecosystem approach and the concept of community integrity. Within an area defined biogeographically through an ecosystem approach, students will be exposed to the initial steps of determining principles, rights, jurisdictions, biodiversity linkages and local potential. Students will then be required to consider relationship development and public participation within the administrative and social frameworks, leading to analysis and transformational education activities by the students in subsequent years.

Community Relations. This course will give students exposure to the concept of community and its influences. Emphasis will be placed upon establishing appropriate levels and types of interactions for the purpose of promoting public participation and sustainable development in the context of related environmental sustainability and ecosystem services. Local action will be considered from a community-based perspective. Students will develop their awareness of potential challenges associated with integrated development involving individuals, People's Organizations (POs), local government units (LGUs), and provincial and national agencies. Participatory approaches will be examined as a means of building multi-sector consensus on the role of biodiversity.

People's Organizations (Relationships and Activities). People's Organizations will be examined in terms of social networking and their capacity as cultural, economic and advocacy agents. The role of LGU interactions with POs will be considered as an integral component of intervention development by non-local agents. Challenges associated with PO development will be reviewed 
based upon local, regional and national experience. The potential development of focused training interventions will be applied to the structure and operation of known POs.

Forestry and Agricultural Land Use. This summer semester course is intended to develop an understanding of forestry and agricultural land use relevant to marine considerations. Students will use their skills developed in previous courses to promote public participation in defining forestry and agricultural land use in a specific area. A written report will be submitted and/or a presentation conducted with emphasis on the links between these two areas and the marine system.

\section{Extensions}

Extensions is an area of service provided by state colleges and universities that focuses on the application of nationally mandated development projects and forms of local innovation. Emphasis is on poverty alleviation and sustainable development. The current framework for the ASCOT Extensions Program was established by author E Macose, in part through his role as Director of Extensions. The program focuses on both biological capacity and public participation developed as part of the action research doctoral study of Macose (2008), with authors P Watts as adviser and E Angara as a thesis committee member. The program has separate areas of emphasis for farmers and fisherfolk. The program involves ASCOT taking a leadership role in sustainable development through the implementation of the Ecosystem Based Community Centered Sustainable Development Organization and Management (ECSOM) Protocol (Roxas 1984). This community-centred approach is based upon systematic public participation at the barangay and municipal levels through municipal planning officers. ASCOT has facilitated the implementation of the ECSOM Protocol by engaging the eight Municipal Development Councils and Coordinators that constitute Aurora Province. There is now a strong link between the ASCOT Extensions Program and the Local Government Units (LGUs) through the Municipal Planning and Development Coordinators who will call for meetings and assist in focused FGDs with organisations including NGOs, People's Organizations, community associations, academic organisations, churches, and the local media.

Future initiatives will be in part driven by a local or community social accounting matrix that links food sources to employment and household activities through a house by house census, household cluster meetings or FGDs and community representation. In the marine environment, approaches need to be bioregional to consider biodiversity. ECSOM is based upon a strong local organisational development protocol for the management of our ecosystems, encompassing connections within and between each other (Roxas 2006). One challenge at ASCOT is that there is a lack of staff with social accounting analytical skills. Staffing constraints could be addressed in two ways: through in-house training and by recruitment, based upon the mobilisation of the 
required financial resources. In a development directly related to the ECSOM initiative, public participation is also being approached in terms of human rights goals and the perceived objectives of the communities. There is also a need to develop focused adult education programs within the Extensions Program that not only inform fisherfolk and related communities, but also empower them to have input and increase their applied understanding.

\section{CONCLUSION}

The partnership and public participation facilitation and building, extensions, and research and teaching activities of ASCOT for the marine environment will continue to develop in a transdisciplinary manner, with a focus on poverty alleviation and ecohealth. The programmatic approach to empowerment in CRM for Aurora Province is centred on the sustainability of marine resources and related livelihoods. Marine resource sustainability is not only a function of biological capacity but must also consider the culture of resource extraction. Therefore, for any form of sustainability to be successful, the primary beneficiaries of the marine system, that is, the fisherfolk, need to be empowered to participate. Academic institutions are centrally placed to take on this crucial leadership role in driving public participation, establishing synergistic collaboration at various levels of governance - such as between government bodies, grassroots organisations and education centres - and institutionalising public participation and empowerment measures through responsive education. The ASCOT programs are an example of the potential for this evolving role.

In economically advanced countries, sustainable development is often seen as the primary responsibility of government. However, the lack of governance infrastructure in less developed countries lends itself to a heightened local level of participation, responsibility and engagement. A focus on public participation may, in fact, be the only possibility for significant movement towards marine sustainability in the Philippines. A primary focus on communication and coordination as a function of broad-based participatory approaches to partnership development is also needed.

Empowerment of local stakeholders, such as fisherfolk, can potentially lead to a broader scale of participation, and even national and eventually international consensus on marine sustainability. Similarly, direct involvement and collaboration between academe and jurisdictions may be critical in establishing participatory strategies to create a holistic and responsive approach to the sustainability of larger marine ecosystem services. This may be particularly true for less developed countries with limited financial resources and high rates of poverty. Academic institutions can play a significant role in pursuing sustainable development, reaching from primary to secondary to adult education as a means of supporting and furthering the sustainable use of coastal and other resources. The integration of sector- and 
discipline-specific perspectives needs to be pursued through programs built on enhanced levels of participatory action research, appropriate extension services, and relevant curriculum and teaching strategies.

\section{REFERENCES}

Acheson, J, Wilson, J \& Steneck, R 1998, 'Managing chaotic fisheries', in F Berkes \& C Folke (eds), Linking social and ecological systems: Management practices and social mechanisms for building resilience, Cambridge University Press, Cambridge.

Adan, W 2004, 'A local government alliance approach to integrated coastal resource management: The Gingoog Bay Development Council experience', in DA-BFAR, In turbulent seas: The status of Philippine marine fisheries, Coastal Resource Management Project of DENR, Cebu City, Philippines, pp. 327-31.

Akester, R, Imson, J, Matteau, Y \& Watts, P 2007, Sustainability: Environment, education, livelihoods ... An international volunteer's perspective on Philippine development, VSO-Philippines, p. 22.

Alava, M \& Cantos, J 2004, 'Marine protected species in the Philippines', in DA-BFAR, In turbulent seas: The status of Philippine marine fisheries, Coastal Resource Management Project of DENR, Cebu City, Philippines, pp. 109-17.

Alcala, A \& Russ G 2006, 'No-take marine reserves and reef fisheries management in the Philippines: A new people power revolution, Ambio, vol. 35 , pp. $245-54$.

Alesna, E, Dizon-Corrales, J \& Cabangbang, A 2004, 'Commercial fisheries licensing system', in DA-BFAR, In turbulent seas: The status of Philippine marine fisheries, Coastal Resource Management Project of DENR, Cebu City, Philippines, pp. 200-01.

Aliño, P, Nanola, C, Campos, W, Hilomen, V, Uychiaoco, A \& Mamauag, S 2004a, 'Philippine coral reef fisheries: Diversity in adversity', in DA-BFAR, In turbulent seas: The status of Philippine marine fisheries, Coastal Resource Management Project of DENR, Cebu City, Philippines, pp. 65-69.

Aliño, P, Atrigenio, M, Quibilan, M \& Tiquio, M 2004b, 'The significance of coastal ecosystem stewardship to fisheries productivity', in DA-BFAR, In turbulent seas: The status of Philippine marine fisheries, Coastal Resource Management Project of DENR, Cebu City, Philippines, pp. 79-83.

Añabieza, M, Pajaro, M, Reyes, G, Tiburcio, F \& Watts, P 2010, 'Philippine alliance of fisherfolk: Ecohealth practitioners for livelihood and food security', EcoHealth, viewed 22 November 2010, www.springerlink.com/ content/e6t8nt32575g71lw/.

Arnstein, S 1969, 'A ladder of citizen participation', Journal of the American Institute of Planning, vol. 35, no. 4, pp. 216-24.

Barut, N, Santos, M \& Garces, L 2004, 'Overview of Philippine marine Fisheries', in DA-BFAR, In turbulent seas: The status of Philippine marine fisheries, Coastal Resource Management Project of DENR, Cebu City, Philippines, pp. 22-31.

Berkes, F \& Folke C 1998, 'Linking social and ecological systems for resilience and sustainability', in F Berkes \& C Folke (eds), Linking social and ecological systems: Management practices and social mechanisms for building resilience, Cambridge University Press, Cambridge, pp. 1-25. 
Carpenter K, Springer V 2005, 'The center of the center of marine shore fish biodiversity: The Philippine islands', Environmental Biology of Fishes, vol. 72, pp. 467-80.

Carreon III, M 2004, 'Information management systems for Philippine fisheries', in DA-BFAR, In turbulent seas: The status of Philippine marine fisheries, Coastal Resource Management Project of DENR, Cebu City, Philippines, pp. 192-96.

Choguill, M 1996, 'A ladder of community participation for underdeveloped countries', Habitat International, vol. 20, no. 3, pp. 431-44.

Christensen, V \& Pauly, D 1995, 'Fish production, catches and the carrying capacity of the world's oceans', Naga, the ICLARM Quarterly, vol. 18, no. 3, pp. 34-40.

Christensen, V \& Pauly, D 1996, 'Ecological modeling for all', Naga, the ICLARM Quarterly, vol. 19, no. 2, pp. 25-26.

DA-BFAR (Department of Agriculture-Bureau of Fisheries and Aquatic Resources) 2004, In turbulent seas: The status of Philippine marine fisheries, Coastal Resource Management Project of DENR (the Department of Environment and Natural Resources), Cebu City, Philippines, viewed 18 November 2010, http://oneocean.org/download/db files/fshprofl.pdf.

Dizon-Corrales, J 2004, 'Regional fisheries management planning: A work in progress', in DA-BFAR, In turbulent seas: The status of Philippine marine fisheries, Coastal Resource Management Project of DENR, Cebu City, Philippines, pp. 269-72.

Eisma, R 2004, 'Local governance for municipal fisheries: Can local governments afford to have coastal resource management as a basic service responsibility?', in DA-BFAR, In turbulent seas: The status of Philippine marine fisheries, Coastal Resource Management Project of DENR, Cebu City, Philippines, pp. 180-83.

Flores, J 2004, 'Fisheries in deep-water areas of the Philippines', in DABFAR, In turbulent seas: The status of Philippine marine fisheries, Coastal Resource Management Project of DENR, Cebu City, Philippines, pp. 72-78.

Food and Agriculture Organization (FAO) 2008, The state of world fisheries and aquaculture 2007, Food and Agriculture Organization (FAO) Information Division, Rome, Italy.

Gomez, E, Licuanan, W, Villanoy, C, Campos, W \& Sajot, C (eds) 2004, Pacific Seaboard R \&D Program - Terminal Report Project $1 \& 2$, University of the Philippines Marine Science Institute, Diliman, Quezon City, Philippines.

Guidote, M 2004, 'Fisheries management and enforcement', in DA-BFAR, In turbulent seas: The status of Philippine marine fisheries, Coastal Resource Management Project of DENR, Cebu City, Philippines, pp. 206-14.

Hermes, R 2004a, 'Integration of fisheries into coastal area management', in DA-BFAR, In turbulent seas: The status of Philippine marine fisheries, Coastal Resource Management Project of DENR, Cebu City, Philippines, pp. 273-76.

Hermes, R 2004b, 'Marine protected areas: Urgent call for an offshore marine sanctuary under Republic Act 8550', in DA-BFAR, In turbulent seas: The status of Philippine marine fisheries, Coastal Resource Management Project of DENR, Cebu City, Philippines, pp. 223-25.

Israel, D 2004, 'Economics and environment in the fisheries sector', in DA-BFAR, In turbulent seas: The status of Philippine marine fisheries, Coastal 
Resource Management Project of DENR, Cebu City, Philippines, pp. 131-37.

Jatulan, W 2004, The evolving role of national government agencies in coastal and fisheries management', in DA-BFAR, In turbulent seas: The status of Philippine marine fisheries, Coastal Resource Management Project of DENR, Cebu City, Philippines, pp. 171-74.

Licuanan, W, Aliño, P, Campos, W, Castillo, G \& Juinio-Menez, M 2006, 'A decision support model for determining sizes of marine protected areas: biophysical considerations', Philippine Agricultural Scientist, vol. 89, pp. $34-47$.

Lowes, J \& Reisch, M 1998, 'Bringing the community into the classroom: Applying the experiences of social work education to service-learning courses in Sociology', Teaching Sociology, vol. 26, no. 4, pp. 292-98.

Luna, C, Silvestre, G, Green, S, Carreon III, M \& White, A 2004a, 'Profiling the status of Philippine marine fisheries: A general introduction and overview', in DA-BFAR, In turbulent seas: The status of Philippine marine fisheries, Coastal Resource Management Project of DENR, Cebu City, Philippines, pp. 3-11.

Luna, C, Silvestre, G, Green, S, Carreon III, M \& White, A 2004b, 'Sustaining Philippine marine fisheries beyond Turbulent Seas: A synopsis of key management issues and opportunities', in DA-BFAR, In turbulent seas: The status of Philippine marine fisheries, Coastal Resource Management Project of DENR, Cebu City, Philippines, pp. 345-58.

Macose, E 2008, 'Initiating intervention: The preparation of a prefeasibility installation project proposal (PFIPP) for ecosystem-based community centered sustainable development organization and management (ECSOM) in the Province of Aurora, Philippines', PhD thesis, SE Asia Interdisciplinary Institute, Manila.

Mamauag, S 2004, Fishery status of Aurora, Philippine Environmental Governance Program, University of the Philippines Marine Science Institute, Diliman, Quezon City, Philippines.

McGlone, M, Jacinto, G, Velasquez I \& Padayao, D 2004, 'Status of water quality in Philippine coastal and marine waters', in DA-BFAR, In turbulent seas: The status of Philippine marine fisheries, Coastal Resource Management Project of DENR, Cebu City, Philippines, pp. 96-108.

Ong, P, Afuang L \& Rosell-Ambal, R (eds) 2002, Philippine biodiversity conservation priorities: A second iteration for the national biodiversity strategy and action plan, DENR, Biodiversity Conservation Program - UP Center for Integrative and Development Studies, Quezon City, Philippines.

Orencio, P 2008, 'A mechanism for inter-local governmental planning and management of fisheries resources: A case study of four municipalities in Baler Bay', Masters thesis, School of Urban and Regional Planning, University of the Philippines, Diliman, Quezon City, Philippines.

Pestaño-Smith, R 2004, 'Challenging the status quo of marine capture fisheries management: The need for public education and policy advocacy programs', in DA-BFAR, In turbulent seas: The status of Philippine marine fisheries, Coastal Resource Management Project of DENR, Cebu City, Philippines, pp. 256-60.

Pido, M 2004, 'An overview of capture fisheries management in the context of integrated coastal management', in DA-BFAR, In turbulent seas: The status of Philippine marine fisheries, Coastal Resource Management Project of DENR, Cebu City, Philippines, pp. 277-81. 
Pinat, N \& Green, S 2004, 'The changing role of local governments: Bohol provincial government and fisheries management', in DA-BFAR, In turbulent seas: The status of Philippine marine fisheries, Coastal Resource Management Project of DENR, Cebu City, Philippines, pp. 184-88.

Reason, P \& Bradbury, H (eds) 2008, The SAGE handbook of action research: Participative inquiry and practice, 2nd edn, Sage, London.

Reed, M 2008, 'Stakeholder participation for environmental management: A literature review', Biological Conservation, vol. 141, pp. 2417-31.

Roberts C, McClean, C, Veron, J, Hawkins, J, Allen, G, McAllister, D, Mittermeier, C, Schueler, F, Spalding, M, Wells, F, Vynne, C, Werner, T 2002, 'Marine biodiversity hotspots and conservation priorities for tropical reefs', Science, vol. 295, pp. 1280-84.

Roxas, S 1984, Community-based organization and management technology, Foundation for Community Organization and Management Technology, Manila.

Roxas, S 2006, 'One nation, three worlds', Philippine Daily Inquirer, Talk of the Town, 2 April, p. A16.

Santos, R 2004, 'Poverty profile in Philippine fisheries', in DA-BFAR, In turbulent seas: The status of Philippine marine fisheries, Coastal Resource Management Project of DENR, Cebu City, Philippines, pp. 138-43.

Silvestre, G \& Pauly, D 2004, 'An overview of tropical coastal fisheries in Asia: An overview of key challenges and opportunities', in DA-BFAR, In turbulent seas: The status of Philippine marine fisheries, Coastal Resource Management Project of DENR, Cebu City, Philippines, pp. 150-67.

Townsend, R 2004, 'Economics of fisheries management in the Philippines', in DA-BFAR, In turbulent seas: The status of Philippine marine fisheries, Coastal Resource Management Project of DENR, Cebu City, Philippines, pp. 127-30.

Trudeau, H 2004, 'Perspectives on a licensing system for municipal fisheries', in DA-BFAR, In turbulent seas: The status of Philippine marine fisheries, Coastal Resource Management Project of DENR, Cebu City, Philippines, pp. 197-99.

UNESCO 2009, 'Marine spatial planning: A step by step approach to ecosystem based management', International Oceanographic Commission, Manual and Guides no. 53, ICAM Dossier no. 6.

Vicente, M (ed.) 2009, Sining-bayan - art of nation building: Social artistry fieldbook, United Nations Development Program, Philippines, viewed 18 November 2010, www.blafi.org.

Watts, P, Angara, E, Roxas, S, Imson, J \& Davies, J 2006, 'Roles and responsibilities for sustainable resource management and food security in the Philippines', SPARK - SE ASIA Natural Resource Management Newsletter, vol. 24 , no. 2 .

White, A \& De Leon, R 2004, 'Mangrove resource decline in the Philippines: Government and community look for new solutions', in DA-BFAR, In turbulent seas: The status of Philippine marine fisheries, Coastal Resource Management Project of DENR, Cebu City, Philippines, pp. 84-89.

Woods L 2006, 'Summary report of the current status of the Global Marine Protected Area Network and of progress monitoring capabilities', Conference of the Parties to the Convention on Biological Diversity Eighth Meeting, Curitiba, Brazil, pp. 1-12. 
Zaragoza, E, Pagdilao, C \& Moreno, E 2004a, 'Overview of the small pelagic fisheries', in DA-BFAR, In turbulent seas: The status of Philippine marine fisheries, Coastal Resource Management Project of DENR, Cebu City, Philippines, pp. 32-37.

Zaragoza, E, Pagdilao, C \& Moreno, E 2004b, 'Fisheries for tuna and other large pelagic fishes', in DA-BFAR, In turbulent seas: The status of Philippine marine fisheries, Coastal Resource Management Project of DENR, Cebu City, Philippines, pp. 38-41. 